\title{
Anti-facemaskism-Politicisation of Face Masks during COVID-19 in the Context of Trump's Plutocratic Populism
}

\author{
Jürgen Rudolph ${ }^{1}$ \\ Ching Sheau Rong ${ }^{2}$ \\ Shannon $\operatorname{Tan}^{3}$
}

\begin{abstract}
The novel coronavirus (COVID-19) pandemic has had a devastating impact around the world. The responses by government leaders around the world have been varied. While certain countries (for instance, Taiwan and New Zealand) excelled in their responses, the Presidency of Donald Trump will perhaps be best remembered because of its populist, antiscientific, and denialist approach towards the pandemic. After providing a brief literature review that focuses on the academic literature on face masks, we show that Trump's absurd responses to the pandemic were not unique amongst populists worldwide. Based on a qualitative analysis of Trump's numerous false and misleading statements about COVID-19, we reconstruct his coronavirus and facemask responses that contributed to the U.S. having the highest coronavirus death toll worldwide. We conclude by highlighting the importance of teaching critical thinking and the careful evaluation of the trustworthiness of sources to avoid falling for fake news and populist propaganda.
\end{abstract}

Keywords: COVID-19, cross-national comparison, face masks, pandemic, populism.

\footnotetext{
${ }^{1}$ Head of Research \& Senior Lecturer, Kaplan Singapore; Editor-in-chief, Journal of Applied Learning \& Teaching. Email: jurgen.rudolph@kaplan.com

${ }^{2}$ Research Intern, Kaplan Singapore

${ }^{3}$ Research Assistant, Kaplan Singapore; Journal Manager, Journal of Applied Learning \& Teaching.
} 


\section{INTRODUCTION}

With the coronavirus pandemic being far from over at the time of writing (April 2021), it may well turn out to be the largest economic, political, and social catastrophe since the Second World War. COVID-19 is also "the great unequalizer" (Zakaria, 2020, p. 151), with the pandemic erasing many of the gains achieved by emerging economies and exacerbating global inequality. Governments have reacted in four different ways to the pandemic. Many democracies have used a scientific, expert-driven approach in addressing the challenging trade-offs between fighting the virus and keeping their economies afloat. In authoritarian countries (with China a prime example), maximum coercion with little regard for civil liberties was observed. Countries under the rule of populists exhibited two additional approaches (that are not mutually exclusive and that could also occur sequentially): denialism; and heavy-handed, though incompetent, responses (The Economist, 2020f).

Pandemics can fuel populism, and populism can fuel pandemics (McKee et al., 2020). Populism is an anti-pluralist, anti-establishment form of ethno-nationalist identity politics (Müller, 2017; Pierson, 2017). In Mudde and Kaltwasser's (2017, p. 6) broadly shared assessment, populism is a "thin ideology" that uses the homogeneous binaries of a "pure people" versus a "corrupt elite". Due to the 'thinness' of populist ideologies, they usually have to be attached to a wide variety of 'thick' ideologies such as nationalism, fascism, or racism, thus justifying populist agendas and explaining how the world is and should be (Mudde \& Kaltwasser, 2017). As populists claim that they alone represent the people, and that their political rivals are illegitimate (Müller, 2017), they run counter to liberal democracy in ignoring the rights of minorities and being cavalier with the rule of law.

In the case of then-US President Donald J Trump, the 'pure people' are, amongst others, white working-class and middle-class voters (often without college degrees) and evangelical Christians in areas outside the most economically dynamic urban centres. The 'pure people's' opponents are everybody who is not like them: Black, Latin, and Asian people; immigrants; Muslims; globalists; technocrats and other experts; LGBTQI+ communities; and a list that undoubtedly goes on much longer. Trump's dualistic world is populated by winners and losers, the strong and the weak, those who agree with the real estate mogul and those who do not and are thus "corrupt, dishonest, unintelligent, or incompetent" (Jamieson \& Taussig, 2017, p. 625). Our characterisation of Trump's populism is not an indictment of white Americans, as it is worth remembering that Trump lost the popular vote both in 2016 and in 2020, and many Republican voters were uncomfortable with his presidential campaigns. However, negative partisanship (Abramowitz \& Webster, 2016) continued to play an important role in the 2020 Presidential Elections in a hyper-polarised country.

While Pierson (2017) appears to discuss the concepts of populism and plutocracy (government by the wealthy) as contradictory, Zakaria (2020) has convincingly combined them as a Janus-faced 'plutocratic populism'. Right-wing populists (exemplified by Trump and others) continuously send the kind of messages that their constituents want to hear. 
Hence, in his 2016 convention speech, Trump had pledged: "I have joined the political arena so that the powerful can no longer beat up on [sic] people that cannot defend themselves".

However, there is a chasm between plutocratic populists' rhetoric and their actions: What they say is not what they do. Once in power, Trump formed a "cabinet of billionaires and multimillionaires" (Klein, 2018, p. 18) and "filled his administration with a mix of the staggeringly wealthy and the staggeringly reactionary" (Pierson, 2017, pp. S106-S107). He then pursued an economic agenda largely comporting with that of the Republican establishment, which was extremely friendly to large corporations and wealthy families, and introduced policies aimed at achieving radical cuts in the American welfare state; sharply reducing taxes for the wealthy; gutting consumer, worker, and environmental protections; and imposing extensive deregulation (Pierson, 2017). These policies were not precisely in the interest of the rural and moderate-income communities that helped Trump win office, and there were unkept electoral promises (such as bringing back jobs and insuring everyone for healthcare at lower cost while delivering high-quality care).

In the next section, we discuss our methodological approach in reconstructing Trump's coronavirus responses with special consideration of his anti-facemaskism - a term apparently coined in an article in October 2020 in The Economist magazine (2020d). After providing a brief literature review that focuses on the academic literature on face masks, we engage in a cross-national comparison of worldwide populist responses to the pandemic that show that Trump's was not an isolated denialist and incompetent response. Based on a qualitative analysis of Trump's numerous lies about COVID-19, we reconstruct his coronavirus and facemask responses. We conclude by highlighting the importance of teaching critical thinking and evaluating the trustworthiness of sources to avoid falling for fake news and populist propaganda.

\section{METHODOLOGY}

Our literature review in Section 3 shows that, despite the novelty of the topic and in addition to numerous (51, to be precise) journalistic articles, there is a growing academic literature about Trump and other populist leaders in relation to COVID-19 (Agnew, 2020; Eberl et al., 2020; Gugushvili et al., 2020; Lasco, 2020; McKee et al., 2020; McQueen et al., 2020; Rutledge, 2020; Stecula \& Pickup, 2021; Vieten, 2020). A glaring gap in the academic literature, though, pertains to Trump's anti-facemaskism. We provide a brief overview of the academic literature on face masks that is quite unanimous when it comes to the usefulness of facemasks in conjunction with other measures in combating the pandemic. A cross-national comparison (briefly referring to populist approaches in nine countries: Belarus, Brazil, Hungary, India, Indonesia, The Philippines, Tanzania, Turkey, and Turkmenistan) in Section 4 enables us to locate Trump's approach to the coronavirus and face masks within a larger global context of populist leaders, deliberately placing Trump's denialism, anti-expertism, and anti-facemaskism in a comparative context. Through a qualitative analysis of Trump's utterances on COVID-19 and face masks, largely via a plethora of journalistic articles, our study explores Trump's denialist and incompetent approach. 


\section{LITERATURE REVIEW}

Google Scholar searches-on "Trump and COVID-19" and "populism and COVID-19yielded less than a dozen peer-reviewed journal articles and book chapters that were relevant to our topic. Amongst them, Rutledge (2020) puts Trump's failure to provide leadership in a time of crisis in historical context, while Agnew (2020) not only blames Trump but also the U.S. government system. Gugushvili et al. (2020) and McKee et al. (2020) point to Trump's disregard for the unnecessary lives lost during the coronavirus pandemic, with McQueen et al. (2020) controversially tracing this back to German philosopher Nietzsche's concept of Superman (Übermensch) with its disdain for ordinary people. Other articles focus on conspiracy theories related to populism (Eberl et al., 2020; Stecula \& Pickup, 2021). In terms of cross-national comparisons, Lasco (2020) usefully compares the "medical populism" of Bolsonaro, Duterte, and Trump, whereas Vieten (2020) focuses on right-wing 'anti-hygienic' demonstrations in Germany. Our work adds to this corpus of research as it is the first academic article to focus on Trump's anti-facemaskism.

The ever more popular social media magnify the numerous false and misleading statements propagated by populists and have led to an 'infodemic' during the pandemic. Social media disseminate fake news and misinformation rapidly, with fact-checks usually spreading slower than fake news on social media (Vosoughi et al., 2018). Fake news manipulates the public's perception of reality and is a great threat to democracy, journalism, and public trust in governments (Zhou \& Zafarani, 2018). In a public health crisis such as COVID-19, fake news are rapidly transmitted through social media much like a real virus, 'infecting its hosts' with falsehoods (van der Linden et al., 2020) and contributing to phenomena such as antifacemaskism and anti-vaccinationism. To combat fake news, media literacy initiatives and 'prebunking' (pre-emptive debunking) are needed, as fake news-spotting and truth-discerning (identifying credible news) skills are learnable (van der Linden et al., 2020). These skills are part of critical thinking. Thinking critically encompasses coming to our own decisions rather than letting others do this on our behalf (Brookfield, 1987). Critical thinkers' refusal "to relinquish the responsibility for making the choices that determine our individual and collective futures" (Brookfield, 1987, p. x) has rarely been as important as during the current pandemic.

The remainder of our literature review provides evidence on the usefulness of face masks during the coronavirus pandemic. The science around the use of face masks to impede the transmission of the coronavirus has advanced rapidly. The 'universal masking' generally mandated in East Asian countries was a key component of their responses to the pandemic, a fact initially overlooked by many Western experts (Zakaria, 2020). With the escalation in infected individuals, the World Health Organization (WHO) encouraged individuals to adopt mask-wearing practices $(B B C, 2020 \mathrm{~b})$. When individuals are not wearing a mask, droplets carrying the virus are directly expelled into the air and could infect others. The COVID-19 virus remains viable in the air for numerous hours in aerosol form (Tang et al., 2020). Moreover, asymptomatic carriers increase the risk of virus-spreading, and pre-symptomatic individuals could be contagious up to 2.5 days before symptom onset (Greenhalgh et al., 2020). 
Esposito et al. (2020) discuss 14 different studies on face masks as a strategy to decrease the rate of transmission. Research proves that face masks aid in avoiding a respiratory infection by preventing inhalation of large droplets and blocking droplets from spreading when individuals cough, sneeze, breathe, or talk (University of Maryland, 2020; Milton et al., 2020). Howard et al. (2021) and Brainard et al. (2020) also investigated the effectiveness of face masks in reducing coronavirus transmission. While their studies arrive at vastly different assessments of the efficacy of face masks, both articles conclude that they constitute a critical barrier during the pandemic.

Implementing mandatory mask-wearing in healthcare facilities significantly dampens the transmission of COVID-19 as it greatly reduces the spread of the virus from asymptomatic or presymptomatic individuals (Seidelman et al., 2020). A study from Hong Kong arrived at similar findings in the context of the general population: enforcing the wearing of face masks aided in mitigating the spread of COVID-19 (Cheng et al., 2020). A comprehensive review by Chu et al. (2020) of 172 observational studies across 16 countries also supports the use of facemasks, together with eye protection, in effectively reducing transmission of COVID-19 amongst the community and in hospital settings. Several studies have shown that implementing compulsory community mask-wearing has reinforced other virus-preventative behaviours like hand hygiene and reduced face-touching (Betsch et al., 2020; Chen et al., 2020; Shiraly et al., 2020). Moreover, a study by Miyazawa et al. (2020) pointed out that the absence of public mask-wearing during the early phases of the pandemic had a significant contribution to COVID-19 death tolls.

Wearing face masks aids in reducing infection rates, but it is not a panacea. It should be done in conjunction with other safety measures such as frequent hand-washing, testing and contact-tracing. Not wearing face masks does not help and exacerbates the coronavirus crisis. The proven efficacy and benefits of mask-wearing should spur governmental leaders to roll out directives for mandatory wearing of face masks in public spaces to reduce the threat of the virus and allow for an earlier resumption of economic activities.

In addition to facemask-wearing, many countries also implemented additional expert-driven safety measures. According to de Bruin et al. (2020), measures include mobility and socioeconomic restrictions, hygiene measures, physical distancing, communication, and international support. Mobility restrictions include active zoning, closed or limited public transportation, and air traffic restrictions (Hellewell et al., 2020). Socio-economic restrictions include restricting social gathering and crowding by closing or limiting places of work and recreation (e.g., suspending bars, restaurants, retail). Countries have also implemented physical distancing of one to two metres between each person and restricted the size of group gatherings. Hygiene measures like frequent washing of hands, sanitising, mask-wearing, and decreased food sharing are encouraged as they limit the risks of spreading the virus via direct or indirect contact (Feng et al., 2020; Leung et al., 2020). Well-coordinated communication channels and international cooperation are vital in risk mitigation measures, as they motivate the public to comply with the measures by building trust, understanding, and acceptance (Hellewell et al., 2020). 


\section{POPULISTS AROUND THE WORLD BETWEEN DENIALISM AND INCOMPETENCE - A CROSS-NATIONAL COMPARISON}

The dismal responses to the pandemic by many populist leaders can be classified as either denialism or incompetence or both. The dualist populist leader as the defender of the 'pure people' usually exhibits anti-expertism against the 'wicked elite' of scientists and doctors (Guest, 2020). Undoubtedly, numerous populist and authoritarian leaders also saw COVID19 as an opportunity to introduce dictatorial 'emergency' measures.

Some of these populist responses are almost comical, but one must not forget that this is a deadly serious matter as populist leaders' denialism, anti-expertism, and incompetent responses had lethal consequences, leading to many hundreds of thousands of preventable deaths. While it is not possible to prove how many deaths were caused by populist leaders, one does not need to look any further than well-governed countries such as New Zealand, Singapore, and Taiwan, whose cumulative death toll was lower than 100 COVID-19 deaths (Statista, 2021).

Amongst the denialists is Turkmenistan's President Berdymukhamedov, who first fined his subjects for donning face masks before ordering everyone to wear them as "a protection against dust'" (The Economist, 2020f). Gurbanguly Berdymukhadmedow also recommended "inhaling the smoke from a burning desert-region plant" to beat the virus (Newkey-Burden, 2020). Another idiosyncratic despot, Belarus's Alexander Lukashenko, dismissed COVID-19 as a "psychosis" and recommended self-protection by "drinking vodka, driving a tractor and steaming in a...sauna" (The Economist, 2020d; 2020e). Populist leaders are often worried about causing a panic and disrupting the economy, and Lukashenko makes for a fine example by having said: "[T]here shouldn't be any panic.... You just have to work, especially now, in a village.... There, the tractor will heal everyone. The fields heal everyone" (cited in Newkey-Burden, 2020).

Tanzania's recently deceased President John Magufuli declared his country to be COVIDfree, even as corpses were secretly stacked in cemeteries at night and the virus spread unchecked through the population (Guest, 2020; The Economist, 2021b). This claimed success against the pandemic was attributed to divine intervention: Churches remained open because the coronavirus was "satanic" and "cannot survive in the body of Christ" (Magufuli, cited in The Economist, 2020a).

Denialism was also rife in Indonesia: Until early March, 2020, the government claimed it had no cases of COVID-19, which the health minister attributed to prayer. The home affairs minister urged the public to eat more bean sprouts and broccoli, while President Joko Widodo preferred traditional herbal remedies (Lindsey \& Mann, 2020). Another denialist is Turkey's Recep Erdoğan, who labelled the head of the Turkish Medical Association for questioning the government's suspiciously low number of COVID-19 cases as a "terrorist" and called for her association to be disbanded (The Economist, 2021a).

Brazil is the country with the second-most Covid-19 deaths (Statista, 2021), exceeded only by the U.S.. Unlike the U.S., Brazil is still ruled by a populist, Jair Bolsonaro, sometimes called the "Trump of the Tropics'. Bolsonaro dismissed the coronavirus as "the sniffles" 
while touting useless and dangerous drugs like hydroxychloroquine (Guest, 2020; The Economist, 2020b). Despite government regulations, Bolsonaro refused to wear a mask (Zakaria, 2020). Bolsonaro also regarded social distancing as unnecessary and railed against lockdowns; moreover, while vaccination efforts remained pathetic as recent as March 2021, Bolsonaro advised the populace to stop "whining" about the deaths and to move on (cited in DeCiccio, 2021).

On occasion, populists switch from denialism to heavy-handed responses while remaining incompetent. After first belittling the COVID-19 threat (Lasco, 2020), The Philippines' Rodrigo Duterte then over-reacted. Strongman Duterte criminalised the poor and ordered the police and military to kill those not complying with lockdown measures: "Shoot them dead.... Instead of causing trouble, I'll send you to the grave" (cited in Tisdall, 2020). India's Prime Minister Modi imposed a tight lockdown, leading to millions of workers losing their jobs and returning from cities to the countryside, "turning packed bus stations into covid-19 hotspots and spreading the virus across India" (Guest, 2020). Furthermore, populists typically excel at scapegoating antagonists, excusing themselves, and simply changing the subject. For instance, India's Modi, despite blaming Muslims for spreading the virus, maintained a high approval rating (Guest, 2020). Having spent years painting Muslims as a "demographic, cultural, sexual, and security threat", the government then portrayed them as a "biohazard" (Saran, cited in The Economist, 2020c).

COVID-19 also created opportunities for populists to assume extraordinary powers, ostensibly to protect public health. Numerous states of emergency were declared. For instance, Hungary's parliament issued a "coronavirus law", giving Prime Minister Orban almost unlimited dictatorial powers in the heart of Europe (The Economist, 2020c). Populists tend to prioritise the economy in which, not seldom, they have a substantial stake. In order to keep the economy going and not causing a panic, they mock social distancing and do not wear face masks. As a result, the populist leaders of the countries with the worst death tollsTrump and his tropical alter ego Bolsonaro-all contracted COVID-19.

\section{FINDINGS AND DISCUSSION: TRUMP'S ANTI-FACEMASKISM IN THE CONTEXT OF HIS DISASTROUS COVID-19 POLICIES}

Jamieson and Taussig (2017) have described Trump's rhetorical signature as Manichean (breaking everything down into good or evil), evidence-flouting, accountability-dodging, and institution-disdaining. While in office, Trump routinely dismissed expert advice, instead relying on "hearsay, anecdote, and suspect information in partisan media" (Jamieson \& Taussig, 2017, p. 620). He also shifted the burden of proof to those who opposed his assertions and shunned responsibility for distributing false and misleading information. In addition, Trump rejects conventional standards of accountability and denies discernible reality (Jamieson \& Taussig, 2017). He insulates his followers from the legacy media by labelling any contradictions as 'fake news', thus attempting to avoid exposure of his own false statements.

Lies are false statements that the originator knows to be false. While not every false statement by Trump may be a lie (as he may not always deceive intentionally, per Hulpke, 2020), make 
no mistake: When a political leader repeats lies frequently, this amounts to a disinformation campaign. The Economist (2020h) has called Trump's contempt for the truth the "most headspinning feature" of his presidency in their judgment: "Nothing Mr Trump says can be believed". In an analysis of Trump's lies, DePaulo (2017) concluded that most lies by Trump were 'cruel' and 'self-serving' - a third type of lies, 'kind lies' (i.e., to spare another's feelings), are notably underrepresented when it comes to the former president (DePaulo, 2017).

Trump's disastrous coronavirus policies predate the advent of the pandemic, with his administration cutting the budgets of key agencies dealing with public health and diseases (Yamey \& Gonsalves, 2020). Later, the world-class Centers for Disease Control and Prevention (CDC) were side-lined by the Coronavirus Task Force, led by the science-denying then-Vice-President Pence. The government's de facto spokesperson on the pandemic was not a scientist but rather then-President Trump himself (McQueen et al., 2020).

Trump's denialism of the pandemic is typical for populists and can be viewed in the context of his anti-scientific anti-expertism. His denialism has been well-documented, for instance, on the Wall of Lies, an art installation documenting Trump's false and misleading statements (Figure 1). Based on The Washington Post's extensive fact-checking, Trump made 30,573 false or misleading claims as president, nearly half of which came in his final year (Kessler, 2021).

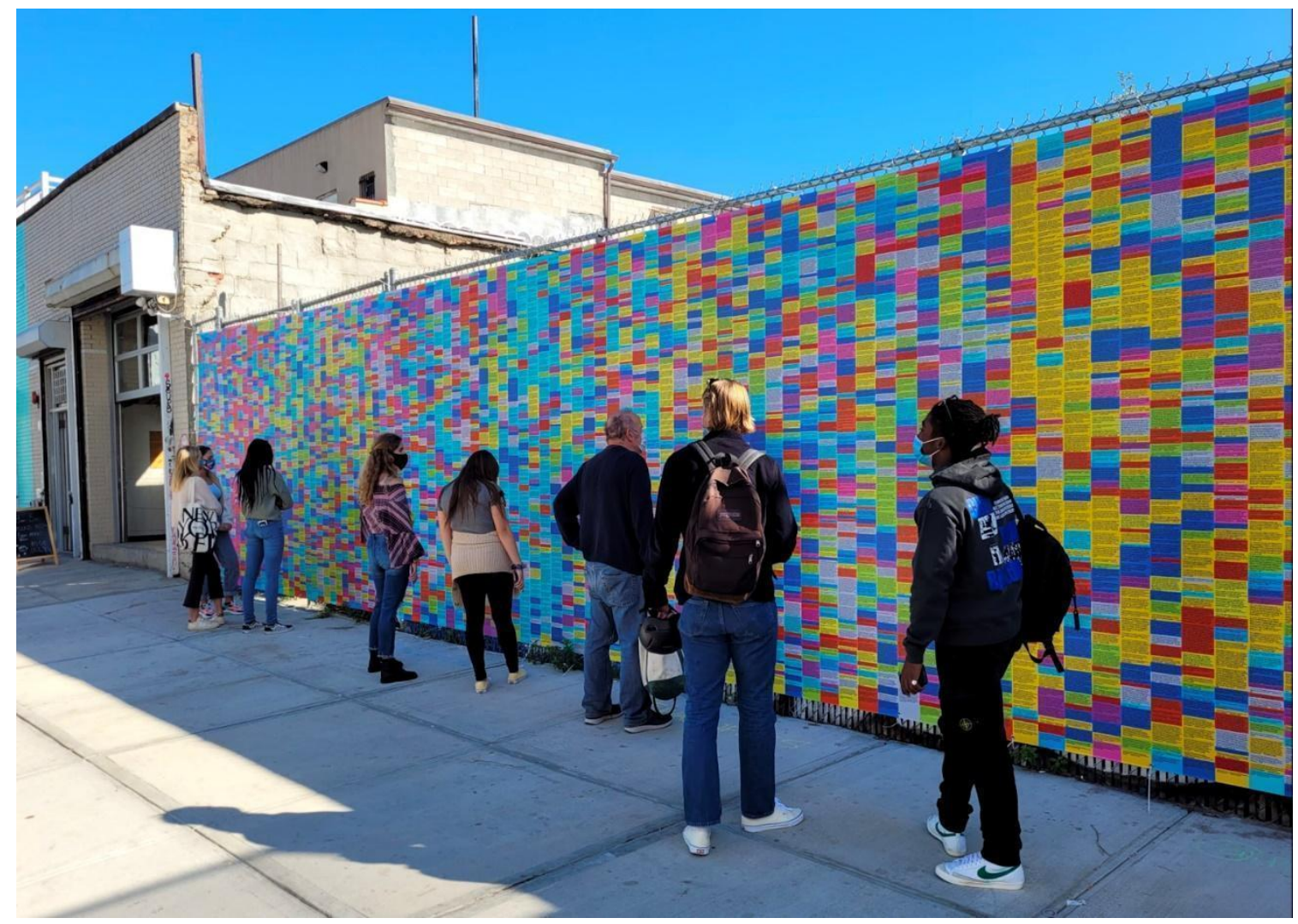

Figure 1. Wall of Lies. The lies are colour-coded, with coronavirus-related 'alternative facts' in green-coloured notes. Source: https://www.dailymaverick.co.za/article/2020-12-14-all-in-all-it-was-all-just-20000-lies-in-thewall/ 
Whilst it would go beyond the confines of our article to discuss all disinformation that Trump and his administration have been spreading about COVID-19, we discuss some of the important instances briefly in order to provide a context for his anti-facemaskism. Towards the beginning of the pandemic, on 30 January 2020, Trump claimed: "We think it's going to have a very good ending for us... that I can assure you" (cited in Oprysko, 2020). On 23 February, he further reassured: "We have it very much under control in this country" (cited in Rieder, 2020). He expected that the coronavirus would disappear on its own "like a miracle" (cited in Paz, 2020). In mid-March, Trump continued to claim American exceptionalism: "The virus will not have a chance against us", with no nation supposedly more prepared or resilient than the U.S. (cited in Woodward et al., 2020). However, when interviewed by legendary investigative journalist Bob Woodward, Trump admitted that he understood the severity of the virus and its threats as early as January 2020. He deceived the public in order to not "create a panic" (cited in Woodward, 2020, p. 10). In February 2020, he told Woodward (2020, p. 13): "This is deadly stuff. You just breathe the air and that's how it's passed".

Numerous exceptionalist claims were made to paint the Trump administration's coronavirus response in a highly positive light, and they also extend to the availability of tests. In March 2020, Trump falsely claimed that "anybody that needs a test, gets a test", while the government's top infection expert, Dr. Fauci admitted: "It is a failing" (cited in Woodward et al., 2020). Trump wrongly contended that the U.S. had the highest rate per capita of COVID19 testing (Sprunt \& Montanaro, 2020). To a mostly unmasked crowd in Oklahoma, Trump suggested slowing down the testing in order to report fewer cases and fare better in international comparisons (Lozano, 2020). [Allegedly, he was joking.] As late as October 2020, Trump embraced the idea of promoting 'herd immunity' while avoiding the termprominent epidemiologists argue that a pursuit of natural herd immunity (instead of social distancing and facemask-wearing) would lead to millions of deaths in the U.S. alone (Gittleson, 2020).

It seems fair to conclude that Trump's denialism and exceptionalist claims were undertaken in the hope to be re-elected as President and to fully reopen the economy. From the populist playbook is also Trump's refusal to admit mistakes and rather blame the 'impure people'/the 'corrupt elite'. Popular targets of Trump's blame-deflecting were Democrats, the media (a.k.a. 'fake news'), state governors, China (the Chinese government certainly deserves blame for its initial lack of transparency during the coronavirus outbreak), experts, and the World Health Organization.

However, more than 400,000 U.S. COVID-19 deaths during Trump's presidency (Stone, 2020) stand as an indictment of his administration's poor preparation for and response to the pandemic. The Trump Death Clock in Times Square (see Figure 2) aimed to show the number of deaths attributable to Trump's inaction during the pandemic. 


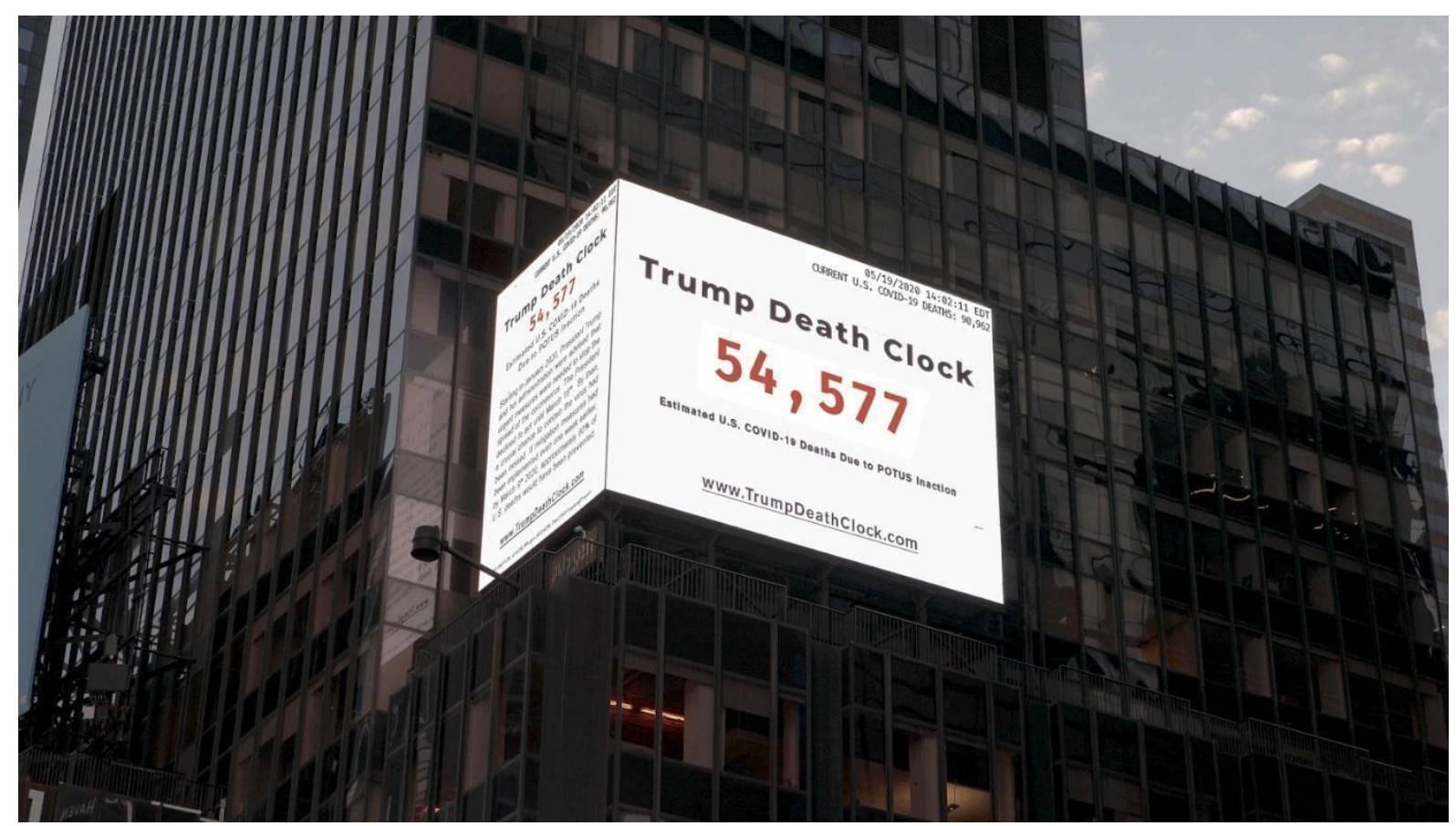

Figure 2. The Trump Death Clock on May 19, 2020. Photo by Andrewsmclain, CCBY 4.0. Source: https://en.wikipedia.org/wiki/Trump_Death_Clock\#/media/File:TRUMP_DEATH_CLOCK_2_051920.jpg

Trump also made numerous unfounded and shocking medical claims. In February 2020, Trump claimed that scientists were "very close to a vaccine" when none was near production (Thielking, 2020). He also promoted unapproved and dangerous preventatives and treatments. In March, Trump promoted hydroxychloroquine for "use immediately" despite a lack of evidence for its effectiveness (Yamey \& Gonsalves, 2020) and claimed to be taking the drug himself as a preventative (The Telegraph, 2020). Hydroxychloroquine was later increasingly linked to deaths (Olorunnipa et al., 2020).

On 23 April 2020, Trump suggested that injecting or drinking disinfectant or bleach could cure COVID-19, prompting experts to urgently warn the public against inhaling or ingesting bleach (Yamey \& Gonsalves, 2020; Zakaria, 2020). Abject and dangerous displays of knownothingness such as the obscurantist promotion of hydroxychloroquine and suggestions of injecting disinfectant are but some instances of Trump's anti-scientific stance and his not caring about the consequences of his words on the lives of people in America and beyond.

One of the most puzzling aspects of Trump's denialism is his anti-facemaskism. From a rational perspective, a plutocratic populist should encourage the wearing of face masks, as it may lead to fewer infections and deaths plus an earlier opening of the economy. However, despite Trump's occasional lukewarm endorsement of the wearing of face masks, it became such a politicised, partisan issue in an election year that he nonetheless hardly ever wore a face mask himself.

In order not to worsen the existing mask shortage in the medical sector, the U.S. government initially did not recommend the use of face masks by the general public (Jankowicz, 2020). As late as end-March 2020, the CDC, in line with WHO guidance, discouraged the use of face masks by healthy members of the general public (Yan, 2020). On 3 April, federal 
officials reversed their earlier guidance, and voluntary mask-wearing was finally recommended, but Trump downplayed the usefulness of face masks in saying: "You don't have to do it. I am choosing not to do it.... It is only a recommendation, voluntary" (cited in Lizza \& Lipman, 2020). He added: "Wearing a face mask as I greet presidents, prime ministers, dictators, kings, queens... I just don't see it for myself" (cited in Vacquez \& Malloy, 2020).

Interestingly, in the U.S., opposition to the practice of wearing face masks, and to orders mandating face mask use, preceded the Trump presidency by almost a century. Such opposition can be traced back to the Spanish flu pandemic of 1918-1919 and the Anti-Mask League of San Francisco (Kane, 2020; see Figure 3). However, a hundred years ago, information was not as readily available as at present. Then, again, disinformation was not as widespread either.

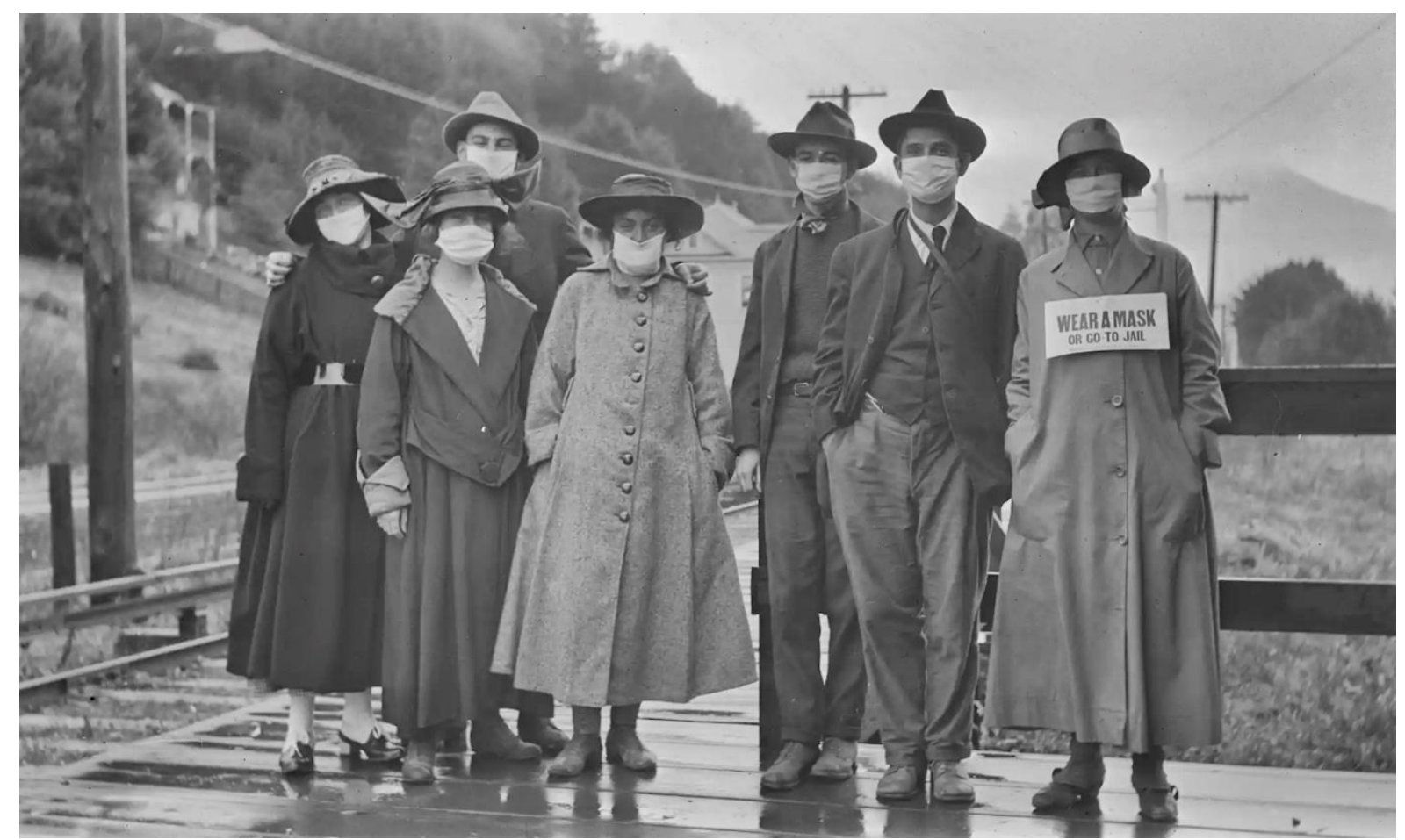

Figure 3: A group of mask-wearing citizens during the flu pandemic of 1918. Photograph: Raymond Coyne/Courtesy of Lucretia Little History Room, Mill Valley Public Library. (C) The Annual Dipsea Race.

In April 2020, a plan to distribute 650 million reusable masks in five-packs to each residential address in the U.S. was scrapped simply to avoid creating a panic (Romm et al., 2020). By May 2020, mask-wearing in the U.S. had become highly politicised. During a press appearance at a Ford plant, Trump did not wear a mask and said that he "didn't want to give the press the pleasure" of seeing him wearing one (cited in Wise, 2020). Despite briefly encouraging mask use in July "if it's necessary" (cited in Choi, 2020), Trump almost never wore masks during his rallies and also did not mandate their use, leading to largely unmasked crowds. 
Lamar Alexander, the Republican chair of the Senate Health Committee, lamented that "the simple lifesaving practice" of 'masking up' had become highly politicised: "If you're for Trump, you don't wear a mask. If you're against Trump, you do" (cited in Bosman, 2020). He also proposed that Trump could "help end this political debate" (cited in Bosman, 2020). Instead, Trump kept mocking his Democratic rival Joe Biden for wearing face masks during his public appearances. In June, Trump commented on Biden's use of masks: "It's like he put a knapsack over his face. He probably likes it that way.... He seems to feel good in a mask..., feels better than he does without the mask, which is a strange situation (cited in Hellmann, 2020). And, in September, Trump asked a partisan crowd: "Did you ever see a man that likes a mask as much as him?... If I were a psychiatrist, I'd say this guy has some big issues" (cited in LeBlanc, 2020). During a presidential debate, Trump again ridiculed Biden for his use of face masks: "I don't wear a mask like him. Every time you see him, he's got a mask. He could be speaking 200 feet away from them, and he shows up with the biggest mask I've ever seen" (cited in Victor et al., 2020).

Whilst the attempt at character assassination of a presidential rival may be unsurprising (even though it involves a critically important matter such as face masks), Trump's continued antiexpertism is also in line with the populist playbook. Instead of supporting science by stating that the evidence on the usefulness of face masks had changed in their favour, he contrasted CDC officials' initial and current advice and made expert advice appear arbitrary and fickle without reason. Trump said: "If you look at Dr. Fauci's original statement, you look at a lot of people, CDC...they said very strongly...'don't wear masks.' Then all of a sudden they went to "wear masks"' (cited in ABC News, 2020).

In late September, Trump held an outdoor ceremony at the White House Rose Garden for Supreme Court nominee Amy Coney Barrett. As many of the 150 attendees did not wear masks, it became a 'super-spreader' event. Trump, his wife, and other members of the White House staff tested positive for the virus after the event (Beckett, 2020). The employees who continued to work physically at the White House were instructed to wear surgical masks and personal protective equipment (PPE) when in close contact with Trump. Nonetheless, the super-spreader event and his own infection with COVID-19 did not end Trump's antifacemaskism. In October, he falsely claimed that $85 \%$ of people who wear masks catch COVID-19, misquoting a CDC study (Dapcevich, 2020).

Instead of recognising masks as part of a scientific, expert-driven approach to combat the pandemic, the issue of mask-wearing vs. anti-facemaskism became another binary tenet of a 'culture war' and 'tribal politics' in the U.S. Instead of a tool, masks had become a symbol, and instead of reflecting fact, they have become ideological (Friedersdorf, 2020). In such a hyper-polarised country, mask-wearing was associated with supporters of the Democratic Party who signalled that they took the pandemic seriously and that they were willing to make personal sacrifices (Lizza \& Lipman, 2020). In contrast, anti-facemaskists were associated largely with the Republican Party, who invoked conspiracy theories and defended their 'personal freedoms', which apparently include the right to infect others with a potentially lethal virus. Trump supported these views and stated that the public should have a "certain freedom" (cited in $B B C, 2020 \mathrm{~d}$ ). 
Culturally, Americans tend to be individualists (rather than collectivists), and especially men may feel less 'macho' when wearing a mask, exhibiting a false sense of masculinity, with non-mask wearers attempting to avoid being perceived as vulnerable, fearful, weak, or 'uncool' (Capraro \& Barcelo, 2020). Wearing a mask was also seen as opposition against Trump (see Figure 4). Face mask skepticism becomes perhaps easier to understand when one puts oneself in the shoes of a blue-collar worker who has become unemployed due to a lockdown, whilst medical experts, technocrats, and journalists, due to their ability to work from anywhere, continue to do well. Perversely, mask skeptics may even be motivated by the belief that experts see them as idiots; thus, shaming them for not wearing masks will only enhance alienation and continued non-mask-wearing (Rosenbaum, 2020). In essence, antifacemaskism brings us back to the populists' 'thin ideology' that uses the homogeneous binaries of a 'pure people' versus a 'corrupt elite' and of 'we' (non-mask-wearers) vs. 'them' (mask wearers).

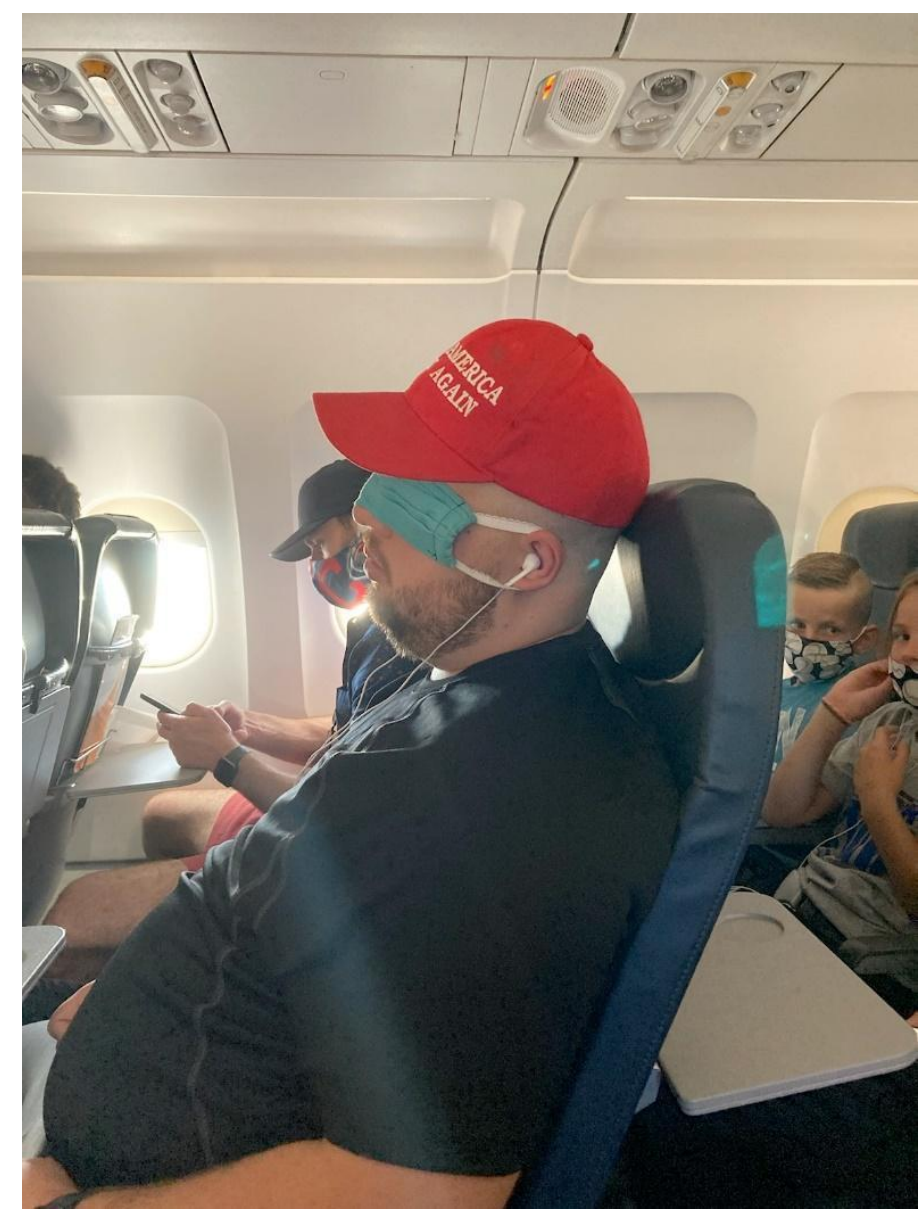

Figure 4. An unidentified Trump supporter wearing a "Make America Great Again" cap, using a face mask on a flight as a sleep mask, conspicuously leaving both his nose and mouth open and unimpeded. Source: Jessica Hazeltine's Twitter account, https://twitter.com/lvnitup22/status/1277283475419258883?ref_src=twsrc\%5Etfw\%7Ctwcamp\%5Etweetembed \%7Ctwterm\%5E1277283475419258883\%7Ctwgr\%5E\%7Ctwcon\%5Es1_\&ref_url=https\%3A\%2F\%2Fwww.fa stcompany.com\%2F90522318\%2Fthis-one-image-shows-how-wearing-a-mask-has-become-politica.

Minority communities have been particularly affected by the politicisation of face masks. When wearing masks, some African-Americans have been the victim of racial profiling due 
to their association with criminals concealing their identity (de la Garza, 2020). The fear of an unknown virus originating from China led to resentment towards Asian-Americans in the U.S., leading to numerous incidents of bullying, discrimination, and ethnic violence against mask-wearing Asian-Americans (Cheung et al., 2020; Ren \& Feagin, 2021; Vachuska, 2020). Trump's labelling of COVID-19 as the "Chinese virus" or "China virus" and his resistance towards face masks has exacerbated the xenophobia and racism (Budhwani \& Sun, 2020; see Figure 5) already plaguing that country.

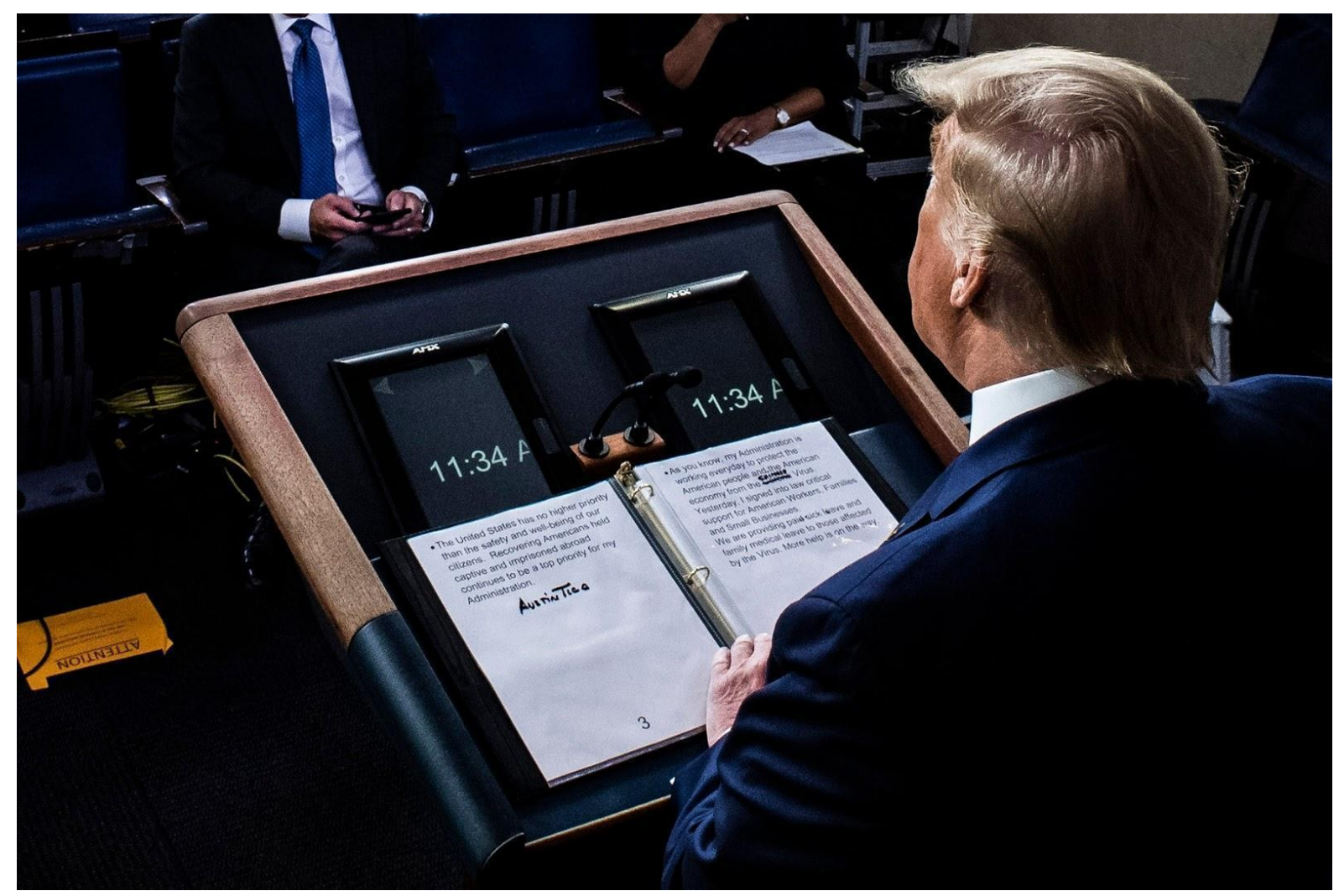

Figure 5. Photo of Trump's typed script with 'corona' crossed out and replaced with 'Chinese'. Source: https://www.washingtonpost.com/graphics/politics/2020/03/19/trump-greatest-sharpiehits/?itid=lk_readmore_manual_36

In April 2020, Trump's comments about "liberating" parts of the country-especially those with Democratic governors-from coronavirus stay-at-home orders put millions of Americans at risk of contracting COVID-19 (AP, 2020). On 6 January 2021, Trump, after he had lost the election, continued to claim falsely that the election had been stolen from him. At a "Save America" rally, he told thousands of his supporters: "If you don't fight like hell, you're not going to have a country anymore" (cited in Woodward, 2021). Subsequently, a mob of about 10,000 invaded the Capitol grounds and some 800 suspected Trump supporters and "domestic terrorists" (then-Senate Minority Leader Chuck Schumer, cited in Choi, 2021) stormed the Capitol in a "failed insurrection" (then-Senate Majority Leader Mitch McConnell, cited in Choi, 2021). 


\section{CONCLUSION}

As could be seen in our cross-national comparison, countries under the rule of populists typically exhibited two non-exclusive approaches to the pandemic - denialism and a heavyhanded, incompetent response. Trump's approach was less heavy-handed and more laissezfaire, but, in line with populist responses around the globe, was characterised by a continuous downplaying of COVID-19 and an incompetent response, exacerbated by numerous false and misleading statements. Our article is the first academic contribution to illustrate Trump's denialism and incompetence with his counter-factual and counter-intuitive (given his plutocratic populism) anti-facemaskism. The populists' dichotomy between a 'pure people' versus a 'corrupt elite' was perversely extended to non-mask-wearers vs. mask-wearers, leading to countless preventable deaths.

Populist leaders like Trump with their numerous misleading and false statements (not only during the coronavirus pandemic) have led to an epistemic crisis. Undoubtedly, Trump is a narcissist whose actions are principally devoted to advancing his own popularity and power; moreover an extreme "escalation of commitment" binds his followers to their leader, thereby giving Trumpism cult-like qualities (Lempinen, 2020). Not all Trump supporters are 'lowinformation voters' with an apathetic lack of awareness who may believe in QAnon, a bizarre conspiracy cult that centres on Trump defending the world against a vast network of Satanic pedophiles that include Democrats and the 'deep state'. There are also 'high-information voters' with 'motivated reasoning' who construct their arguments to arrive at a preferred conclusion (Klein, 2015).

Political theorist Hannah Arendt (2006) has described an individual's inability to differentiate fact from fiction as typical for totalitarian states and spoke in this context of the banality of evil. Populist governments' denialism and failures to combat the coronavirus swiftly and effectively can be considered evil, as despite having the expertise of top scientists at their beck and call, they chose anti-scientific routes in the interest of their own power preservation and economic agenda. An education for critical thinking and investigation to combat fake news and populist propaganda has never been as important as now in the age of social media (Kefalaki \& Karanicolas, 2020).

More research is needed that details other populists' approaches to COVID-19, while more systematic comparisons between populist approaches to the pandemic would also be worthwhile. In addition, there are opportunities for empirical research using primary data. While our article was written in the midst of the pandemic, it is hoped that COVID-19 will eventually be relegated to the scrapheap of history, allowing for more detached perspectives. Defeating the virus will require fighting populism and other approaches disdained by populists, specifically those driven by science, expertise, rationality, openness, and international cooperation. 


\section{REFERENCES}

ABC News. (2020, September 16). Trump's ABC News town hall: Trump responds to a question on a national mask mandate [Video]. Youtube. https://www.youtube.com/watch?v=vqtm6LNM44k

Abramowitz, A. I., \& Webster, S. (2016). The rise of negative partisanship and the nationalization of US elections in the 21st century. Electoral Studies, 41, 12-22.

Agnew, J. (2020). American "populism" and the spatial contradictions of US Government in the time of COVID-19. Geopolitica(s), 11, 15-23.

Arendt, H. (2006). Eichmann in Jerusalem: A Report on the Banality of Evil. Penguin.

Associated Press [AP] (2020, April 17). Inslee blasts Trump for "fomenting domestic rebellion." https://apnews.com/article/33321f4b5bac46eee8c5bd2b2a96fb6d

$B B C$. (2020a, June 6). Coronavirus: WHO advises to wear masks in public areas. https://www.bbc.com/news/health-52945210

BBC. (2020b, July 18). Coronavirus: Donald Trump vows not to order Americans to wear masks. https://www.bbc.com/news/world-us-canada-53453468

Beckett, L. (2021, January 7). Scrutiny on Rose Garden event after Kellyanne Conway and other guests test positive for Covid. The Guardian. https://www.theguardian.com/us-news/2020/oct/02/kellyanneconway-covid-19-rose-garden-event

Betsch, C., Korn, L., Sprengholz, P., Felgendreff, L., Eitze, S., Schmid, P., \& Böhm, R. (2020). Social and behavioral consequences of mask policies during the COVID-19 pandemic. Proceedings of the National Academy of Sciences, 117(36), 21851-21853. https://doi.org/10.1073/pnas.2011674117

Blake, A. (2020, March 19). Notetaker in chief: Trump's presidency as told through a black marker. The Washington Post. https://www.washingtonpost.com/graphics/politics/2020/03/19/trump-greatestsharpie-hits/?itid=lk_readmore_manual_36

Bosman, J. (2020, July 1). Amid virus surge, republicans abruptly urge masks despite Trump's resistance. The New York Times, https://www.nytimes.com/2020/07/01/us/coronavirus-masks.html

Brainard, J., Jones, N. R., Lake, I. R., Hooper, L., \& Hunter, P. R. (2020). Community use of face masks and similar barriers to prevent respiratory illness such as COVID-19: A rapid scoping review. Eurosurveillance, 25(49), 1-14.

Brookfield, S. D. (1987). Developing critical thinkers. Challenging adults to explore alternative ways of thinking and acting. Jossey Bass.

Budhwani, H., \& Sun, R. (2020). Creating COVID-19 stigma by referencing the novel coronavirus as the "chinese virus" on twitter: Quantitative analysis of social media data. Journal of Medical Internet Research, 22(5), 1-7. https://doi.org/10.2196/19301

Capraro, V., \& Barcelo, H. (2020). The effect of messaging and gender on intentions to wear a face covering to slow down COVID-19 transmission. arXiv preprint arXiv:2005.05467.

Chen, Y. J., Qin, G., Chen, J., Xu, J. L., Feng, D. Y., Wu, X. Y., \& Li, X. (2020). Comparison of face-touching behaviors before and during the coronavirus disease 2019 pandemic. JAMA Network Open, 3(7), e2016924. https://doi.org/10.1001/jamanetworkopen.2020.16924

Cheng, V. C. C., Wong, S. C., Chuang, V. W. M., So, S. Y. C., Chen, J. H. K., Sridhar, S., To, K. K. W., Chan, J. F. W., Hung, I. F. N., Ho, P. L., \& Yuen, K. Y. (2020). The role of community-wide wearing of face mask for control of coronavirus disease 2019 (COVID-19) epidemic due to SARS-CoV-2. Journal of Infection, 81(1), 107-114. https://doi.org/10.1016/j.jinf.2020.04.024 
Cheung, H., Feng, Z., \& Deng, B. (2020, May 27). Coronavirus: What attacks on Asians reveal about American identity. $B B C$, https://www.bbc.com/news/world-us-canada-52714804

Choi, M. (2020, July 14). Trump, in full reversal, urges Americans to wear masks. Politico, https://www.politico.com/news/2020/07/14/trump-urges-americans-to-wear-masks-361836

Choi, M. (2021, January 6). 'They failed': McConnell condemns rioters who stormed the Capitol. Politico, https://www.politico.com/news/2021/01/06/mcconnell-condemns-rioters-in-congress-as-failedinsurrection-455660

Chu, D. K., Akl, E. A., Duda, S., Solo, K., Yaacoub, S., Schünemann, H. J., Chu, D. K., Akl, E. A., El-harakeh, A., Bognanni, A., Lotfi, T., Loeb, M., Hajizadeh, A., Bak, A., Izcovich, A., Cuello-Garcia, C. A., Chen, C., Harris, D. J., Borowiack, E., . . Schünemann, H. J. (2020). Physical distancing, face masks, and eye protection to prevent person-to-person transmission of SARS-CoV-2 and COVID-19: a systematic review and meta-analysis. The Lancet, 395(10242), 1973-1987. https://doi.org/10.1016/s0140-6736(20)31142-9

Dapcevich, M. (2020, October 16). Did CDC report 'majority' of people Who contracted COVID-19 wore masks? Snopes, https:/www.snopes.com/fact-check/cdc-report-majority-wore-masks/

de Bruin, Y. B., Lequarre, A. S., McCourt, J., Clevestig, P., Pigazzani, F., Jeddi, M. Z., Colosio, C., \& Goulart, M. (2020). Initial impacts of global risk mitigation measures taken during the combatting of the COVID-19 pandemic. Safety Science, 128, 1-8.

DeCiccio, E. (2021, 31 March). Covid in Brazil 'completely out of control,' says Sao Paulo-based reporter. $C N B C$, https://www.cnbc.com/2021/03/30/covid-in-brazil-completely-out-of-control-says-sao-paulobased-reporter.html

De la Garza, A. (2020, April 16). 'It conjures up every racial stereotype.' For black men, homemade masks may be a risk all their own. Time, https://time.com/5821250/homemask-masks-racial-stereotypes/

DePaulo, B. (2017, December 9). How President Trump's lies are different from other people's. Psychology Today, https://www.psychologytoday.com/us/blog/living-single/201712/how-president-trumps-liesare-different-other-peoples

Eberl, J. M., Huber, R. A., \& Greussing, E. (2020). From Populism to the 'Plandemic': Why populists believe in COVID-19 conspiracies. Journal of Elections, Public Opinion and Parties, 1-18.

Esposito, S., Principi, N., Leung, C. C., \& Migliori, G. B. (2020). Universal use of face masks for success against COVID-19: Evidence and implications for prevention policies. European Respiratory Journal, 55(6), 1-5.

Feng, S., Shen, C., Xia, N., Song, W., Fan, M., \& Cowling, B. J. (2020). Rational use of face masks in the COVID-19 pandemic. The Lancet Respiratory Medicine, 8(5), 434-436.

Friedersdorf (2020, May 5). Masks are a tool, not a symbol. The Atlantic, https://www.theatlantic.com/ideas/archive/2020/05/masks-are-tool-not-symbol/611134/

Gittleson, B. (2020, October 16). Trump embraces idea behind 'herd immunity' as Fauci calls concept 'total nonsense'. $A B C$ News, https://abcnews.go.com/Politics/trump-embraces-idea-herd-immunity-faucicalls-concept/story?id=73634243

Greenhalgh, T., Schmid, M. B., Czypionka, T., Bassler, D., \& Gruer, L. (2020). Face masks for the public during the covid-19 crisis. The BMJ, 369, 1-4.

Guest, R. (2020, November 17). The pandemic showed that populists are not good at governing. The Economist, https://www.economist.com/the-world-ahead/2020/11/17/the-pandemic-showed-that-populists-are-nogood-at-governing

Gugushvili, A., Koltai, J., Stuckler, D., \& McKee, M. (2020). Votes, populism, and pandemics. International Journal of Public Health, 65(6), 721-722. 
Hazeltine, J. (2020, June 29). An unidentified Trump supporter wearing a "Make America Great Again" cap, using a face mask on a flight as a sleep mask, conspicuously leaving both his nose and mouth open and unimpeded.

https://twitter.com/lvnitup22/status/1277283475419258883?ref_src=twsrc\%5Etfw\%7Ctwcamp\%5Etw eetembed\%7Ctwterm\%5E1277283475419258883\%7Ctwgr\%5E\%7Ctwcon\%5Es1_\&ref_url=https\%3 A\%2F\%2Fwww.fastcompany.com\%2F90522318\%2Fthis-one-image-shows-how-wearing-a-mask-hasbecome-politica

Hellewell, J., Abbott, S., Gimma, A., Bosse, N. I., Jarvis, C. I., Russell, T. W., Munday, J. D., Kucharski, A. J. K., Edmund, W. J., \& Eggo, R. M. (2020). Feasibility of controlling COVID-19 outbreaks by isolation of cases and contacts. The Lancet Global Health, 8(4), 488-496.

Hellmann, J. (2020, June 18). Mask-wearing becomes political even as some governors ease resistance. The Hill, https://thehill.com/policy/healthcare/503456-mask-wearing-becomes-political-even-as-somegovernors-ease-resistance

Howard, J., Huang, A., Li, Z., Tufekci, Z., Zdimal, V., van der Westhuizen, H. M., ... \& Delft, A. V., Price, A., L. F., Tang, L-H., Tang, V., Watson, L. G., Bax, C. E., Shaikh, R., Questier, F. D. H., Chu, L. F., Ramirez, C. M., \& Rimoin, A. W. (2021). An evidence review of face masks against COVID-19. Proceedings of the National Academy of Sciences, 118(4), 1-12. https://www.pnas.org/content/pnas/118/4/e2014564118.full.pdf

Hulpke, J. F. (2020). To tell the truth sometimes it pays to lie. Journal of Applied Learning and Teaching, 3(2), 89-99.

Jamieson, K. H., \& Taussig, D. (2017). Disruption, demonization, deliverance, and norm destruction: The rhetorical signature of Donald J. Trump. Political Science Quarterly, 132(4), 619-651.

Jankowicz, M. (2020, June 15). Fauci said US government held off promoting face masks because it knew shortages were so bad that even doctors couldn't get enough. Business Insider, https://www.businessinsider.com/fauci-mask-advice-was-because-doctors-shortages-from-the-start2020-6

Kane, P. (2020, April 29). The anti-mask league: Lockdown protests draw parallels to 1918 pandemic. The Guardian, https://www.theguardian.com/world/2020/apr/29/coronavirus-pandemic-1918-protestscalifornia

Kefalaki, M., \& Karanicolas, S. (2020). Communication's rough navigations: 'Fake' news in a time of a global crisis. Journal of Applied Learning and Teaching, 3(1), 29-41.

Kessler, G. (2021, January 23). Trump made 30,573 false or misleading claims as president. Nearly half cam in his final year. The Washington Post, https://web.archive.org/web/20210124185206/https://www.washingtonpost.com/politics/how-factchecker-tracked-trump-claims/2021/01/23/ad04b69a-5c1d-11eb-a976-bad6431e03e2_story.html

Klein, E. (2015, June 8). Why the most informed voters are often the most badly misled. Vox, https://www.vox.com/2015/6/8/8740897/informed-voters-may-not-be-better-voters

Klein, N. (2018). No is not enough. Penguin.

Lasco, G. (2020). Medical populism and the COVID-19 pandemic. Global Public Health, 15(10), 1417-1429.

LeBlanc, P. (2020, September 4). Trump mocks Biden for wearing mask: 'Did you ever see a man that likes a mask as much as him?' $C N N$, https://edition.cnn.com/2020/09/03/politics/trump-biden-coronavirusmask/index.html

Lempinen, E. (2020, December 7). Despite drift towards authoritarianism, Trump voters stay loyal. Why? Berkeley News, https://news.berkeley.edu/2020/12/07/despite-drift-toward-authoritarianism-trumpvoters-stay-loyal-why/ 
Leung, C. C., Lam, T. H., \& Cheng, K. K. (2020). Mass masking in the COVID-19 epidemic: People need guidance. Lancet, 395(10228), 945-947.

Lindsey, T., \& Mann, T. (2020, April 8). Indonesia was in denial over coronavirus. Now it may be facing a looming disaster. The Conversation, https://theconversation.com/indonesia-was-in-denial-overcoronavirus-now-it-may-be-facing-a-looming-disaster-135436

Lizza, R., \& Lipman, D. (2020 May 1). Wearing a mask is for smug liberals. Refusing to is for reckless Republicans. Politico, https://www.politico.com/news/2020/05/01/masks-politics-coronavirus-227765

Lozano, A. V. (2020, June 21). Trump tells Tulsa crowd he wanted to 'slow down' COVID-19 testing; White House says he was joking. NBC News, https://www.nbcnews.com/politics/2020-election/trump-tellstulsa-crowd-he-wanted-slow-down-covid-19-n1231658

McKee, M., Gugushvili, A., Koltai, J., \& Stuckler, D. (2020). Are populist leaders creating the conditions for the spread of COVID-19?; Comment on "A scoping review of populist radical right parties' influence on welfare policy and its implications for population health in Europe". International journal of health policy and management, , $x(\mathrm{x}), 1-5$.

Mclain, A. (2020, May 19). The Trump death clock on May 19, 2020. As of January 5, 2021, the number is over 350,664 .

https://en.wikipedia.org/wiki/Trump_Death_Clock\#/media/File:TRUMP_DEATH_CLOCK_2_051920 .jpg

McQueen, D., Farache, F., \& Grigore, G. (2020). A revaluation of all values: Nietzschean populism and Covid19. In Values and Corporate Responsibility (pp. 279-311). Palgrave Macmillan, Cham.

Milton, D. K., Fabian, M. P., Cowling, B. J., Grantham, M. L., \& McDevitt, J. J. (2013). Influenza virus aerosols in human exhaled breath: Particle size, culturability, and effect of surgical masks. PLoS Pathogens, 9(3), e1003205. https://doi.org/10.1371/journal.ppat.1003205

Miyazawa, D., \& Kaneko, G. (in press). Face mask wearing rate predicts COVID-19 death rates across countries. MedRxiv.

Mudde, C., \& Kaltwasser, C. R. (2017). Populism: A very short introduction. Oxford University Press.

Müller, J. W. (2017). What is populism? Penguin UK.

Newkey-Burden, C. (2020, April 24). Trump suggests disinfectant cure for coronavirus - five other weird ideas from world leaders. The Week, https://www.theweek.co.uk/106774/trump-suggests-disinfectant-curefor-coronavirus-five-other-weird-ideas-from-world-leaders

Olorunnipa, T., Cha, A.E., \& McGinley, L. (2020, May 15). Drug promoted by Trump as coronavirus 'game changer' increasingly linked to deaths. Washington Post, https://www.washingtonpost.com/politics/drug-promoted-by-trump-as-coronavirus-game-changerincreasingly-linked-to-deaths/2020/05/15/85d024fe-96bd-11ea-9f5e-56d8239bf9ad_story.html

Oprysko C. (2020, January 30). Trump: Coronavirus will have 'a very good ending for us.' Politico, https://www.politico.com/news/2020/01/30/trump-close-cooperation-china-coronavirus-109701.

Paz, C. (2020, November 3). All the President's lies about the coronavirus. The Atlantic, https://www.theatlantic.com/politics/archive/2020/11/trumps-lies-about-coronavirus/608647/

Pierson, P. (2017). American hybrid: Donald Trump and the strange merger of populism and plutocracy. The British journal of sociology, 68, S105-S119.

Ren, J., \& Feagin, J. (2021). Face mask symbolism in anti-asian hate crimes. Ethnic and Racial Studies, 44(5), 746-758. https://doi.org/10.1080/01419870.2020.1826553

Rieder R. (2020, March 18). Trump's statements about the coronavirus. Factcheck.org, https://www.factcheck.org/2020/03/trumps-statements-about-the-coronavirus/ 
Rosenbaum, L. (2020). Tribal truce - how can we bridge the partisan divide and conquer covid? The New England Journal of Medicine, 383(17), 1682-1685. https://doi.org/10.1056/NEJMms2027985

Rutledge, P. E. (2020). Trump, Covid-19, and the war on expertise. The American Review of Public Administration, 50(6-7), 505-511.

Seidelman, J. L., Lewis, S. S., Advani, S. D., Akinboyo, I. C., Epling, C., Case, M., Said, K., Yancey, W., Stiegel, M., Schwartz, A., Stout, J., Sexton, D. J., \& Smith, B. A. (2020). Universal masking is an effective strategy to flatten the severe acute respiratory coronavirus virus 2 (SARS-CoV-2) healthcare worker epidemiologic curve. Infection Control \& Hospital Epidemiology, 41(12), 1466-1467. https://doi.org/10.1017/ice.2020.313

Shiraly, R., Shayan, Z., \& McLaws, M. L. (2020). Face touching in the time of COVID-19 in Shiraz, Iran. American Journal of Infection Control, 48(12), 1559-1561. https://doi.org/10.1016/j.ajic.2020.08.009

Sprunt, B., \& Montanaro, D. (2020, April 2). Fact check: Trump claims U.S. testing for coronavirus most per capita -- it's not. NPR, https://www.npr.org/sections/coronavirus-liveupdates/2020/04/02/826368789/fact-check-trump-claims-u-s-testing-for-coronavirus-most-per-capitaits-not

Statista (2021, March 31). Number of novel coronavirus (COVID-19) deaths worldwide as of March 31, 2021, by country. https://www.statista.com/statistics/1093256/novel-coronavirus-2019ncov-deathsworldwide-by-country/

Stecula, D. A., \& Pickup, M. (2021). How populism and conservative media fuel conspiracy beliefs about COVID-19 and what it means for COVID-19 behaviors. Research \& Politics, 8(1), 1-9. https://doi.org/10.1177/2053168021993979

Stone, W. (2021, January 20). On Trump's last full day, nation records 400,000 Covid deaths. Kaiser Health News. $\quad$ https://khn.org/news/nation-records-400000-covid-deaths-on-last-day-of-donald-trumppresidency/

Tang, S., Mao, Y., Jones, R. M., Tan, Q., Ji, J. S., Li, N., Shen J., Lv, Y., Pan, L., Ding, P., Wang, X., Wang, Y., MacIntyre, R., \& Shi, X. (2020). Aerosol transmission of SARS-CoV-2? Evidence, prevention and control. Environment international, 144, 1-10.

The Economist (2020a, March 28). The coronavirus could devastate poor countries. https://www.economist.com/leaders/2020/03/26/the-coronavirus-could-devastate-poor-countries

The Economist (2020b, March 30). Brazil's losing battle against Covid-19. https://www.economist.com/theamericas/2020/05/28/brazils-losing-battle-against-covid-19

The Economist. (2020c, April 25). Would-be autocrats are using covid-19 as an excuse to grab more power. https://www.economist.com/international/2020/04/23/would-be-autocrats-are-using-covid-19-as-anexcuse-to-grab-more-pow

The Economist. (2020d, June 20). Waving slippers at the "cockroach" president of Belarus. https://www.economist.com/europe/2020/06/20/waving-slippers-at-the-cockroach-president-of-belarus

The Economist. (2020e, July 30). The right way to get rid of President Alexander Lukashenko. https://www.economist.com/leaders/2020/07/30/the-right-way-to-get-rid-of-president-alexanderlukashenkoer

The Economist. (2020f, August 29). Politics is spreading covid-19 in Indonesia and the Philippines. https:/www.economist.com/asia/2020/08/29/politics-is-spreading-covid-19-in-indonesia-and-thephilippines

The Economist. (2020g, October 10). The virus has hit president Donald Trump and his re-election hopes. https://www.economist.com/united-states/2020/10/10/the-virus-has-hit-president-donald-trump-andhis-re-election-hopes 
Journal of Education, Innovation, and Communication (JEICOM) Vol. 3, Issue 1, June 2021, DOI: https://doi.org/10.34097/jeicom-3-1-june21-3

The Economist. (2020h, October 29). Why it has to be Biden. https://www.economist.com/leaders/2020/10/29/why-it-has-to-be-biden

The Economist. (2021a, January 16). Covid-19 and repression in Turkey. https://www.economist.com/europe/2021/01/16/covid-19-and-repression-in-turkey

The Economist. (2021b, April 3). Tanzania's new president surely can't be worse than the old one. https://www.economist.com/middle-east-and-africa/2021/04/03/tanzanias-new-president-surely-cantbe-worse-than-the-old-one

The Telegraph. (2020, May 19). Donald Trump says he takes hydroxychloroquine drug for Covid-19 [Video]. Youtube. https://www.youtube.com/watch?v=JsfqJ1TkgP0

Thielking, M. (2020, February 26). Trump is no stranger to misinformation. But with the coronavirus experts say that's dangerous. STAT News, https://www.statnews.com/2020/02/26/trump-mixed-messages-oncoronavirus/

Tisdall, S. (2020, April 26). From Trump to Erdoğan, men who behave badly make the worst leaders in a pandemic. The Guardian, https://www.theguardian.com/commentisfree/2020/apr/26/trump-to-erdoganmen-who-behave-badly-make-worst-leaders-pandemic-covid-19

University of Maryland. (2020). Wearing surgical masks in public could help slow COVID-19 pandemic's advance: Masks may limit the spread diseases including influenza, rhinoviruses and coronaviruses. https://www.sciencedaily.com/releases/2020/04/200403132345.htm

Vachuska, K. F. (2020). Initial effects of the coronavirus pandemic on racial prejudice in the United States: Evidence from Google trends. https://doi.org/10.31235/osf.io/bgpk3

Vacquez, M., \& Malloy, A. (2020, July 1). Trump says he's 'all for masks,' but believes coronavirus will 'disappear'. CNN, https://edition.cnn.com/2020/07/01/politics/donald-trump-maskscoronavirus/index.html

Van der Linden, S., Roozenbeek, J., \& Compton, J. (2020). Inoculating against fake news about COVID-19. Frontiers in Psychology, 11, 2928.

Victor, D., Serviss, L. \& Paybarah, A. (2020, October 2). In his own words, Trump on the coronavirus and masks. The New York Times, https://www.nytimes.com/2020/10/02/us/politics/donald-trumpmasks.html

Vieten, U. M. (2020). The "new normal" and "pandemic populism": The covid-19 crisis and anti-hygienic mobilisation of the far-right. Social Sciences, 9(9), 1-14.

Vosoughi, S., Roy, D., \& Aral, S. (2018). The spread of true and false news online. Science, 359(6380), 11461151.

Wentzel, A. (2020, December 14). All in all, it was all just 20,000 lies in the wall. https://www.dailymaverick.co.za/article/2020-12-14-all-in-all-it-was-all-just-20000-lies-in-the-wall/

Wise, A. (2020, May 21). Trump briefly dons a face mask at Ford plant, away from media view. NPR.org, https://www.npr.org/sections/coronavirus-live-updates/2020/05/21/860587196/trump-briefly-donsface-mask-at-ford-plant-away-from-media-view

Woodward, B. (2020). Rage. Simon \& Schuster.

Woodward, C. (2021, January 14). AP fact check: Trump's call to action distorted in debate. Associated Press, https://apnews.com/article/fact-check-trump-us-capitol-remarks-221518bc174f9bc3dd6e108e653ed08d

Woodward, C., Yen, H., \& Rising, D. (2020, March 14). AP fact check: Trump, American exceptionalism and the virus. Associated Press, https://apnews.com/article/19963ea122c12eb72b8f0ff14e84b1b7

Yamey, G., \& Gonsalves, G. (2020). Donald Trump: A political determinant of covid-19. The BMJ, 369, 1-2. https://doi.org/10.1136/bmj.m1643 
Yan, H. (2020, June 25). Why face mask guidance has changed so much -- and how wearing masks can protect the economy. CNN, _ https://edition.cnn.com/2020/06/25/health/face-mask-guidance-covid19/index.html

Zakaria, F. (2020). Ten lessons for a post-pandemic world. W.W. Norton \& Company.

Zhou, X., \& Zafarani, R. (2018). Fake news: A survey of research, detection methods, and opportunities. arXiv preprint arXiv:1812.00315, 2. 